\title{
Flame Atomic Absorption Determination of Gold Ion in Aqueous Samples after Preconcentration Using 9-Acridinylamine Functionalized $\gamma$-Alumina Nanoparticles
}

\author{
Mohammad Karimi, Vahid Amani, Forouzan Aboufazeli, Hamid Reza Lotfi Zadeh Zhad, \\ Omid Sadeghi, and Ezzatollah Najafi
}

Department of Chemistry, Islamic Azad University, Shahr-e-Rey Branch, P.O. Box 18735-334, Tehran, Iran

Correspondence should be addressed to Ezzatollah Najafi; ezzatollah.najafi@gmail.com

Received 12 June 2012; Accepted 6 December 2012

Academic Editor: Huu Hao Ngo

Copyright (C) 2013 Mohammad Karimi et al. This is an open access article distributed under the Creative Commons Attribution License, which permits unrestricted use, distribution, and reproduction in any medium, provided the original work is properly cited.

\begin{abstract}
A simple and sensitive solid phase extraction utilizing 9-acridinylamine functionalized alumina nanoparticles was developed, and their potential use for preconcentration and subsequent determination of gold by flame atomic absorption spectrometry (FAAS) was investigated. A number of parameters, namely, type, concentration, and volume of eluent, $\mathrm{pH}$ of the sample solution, flow rate of extraction, and volume of the sample, were evaluated. The effect of a variety of ions on preconcentration and recovery was also investigated. Gold ions were found to be recovered quantitatively at pH 3.0, with $0.1 \mathrm{~mol} \mathrm{~L}^{-1}$ thiourea in $2 \mathrm{~mol} \mathrm{~L}^{-1} \mathrm{H}_{2} \mathrm{SO}_{4}$ as eluent. The limit of detection (LOD), defined as five times the standard deviation of the blank, was determined to be lower than $13.0 \mathrm{ppb}$. Under optimum conditions, the accuracy and precision (RSD\%) of the method were $>98.0$ and $<1.5 \%$, respectively. To gauge its ability in terms of application to real samples, the proposed method was successfully applied for determination of gold concentration in waste water samples and one soil standard material, and satisfactory results were obtained.
\end{abstract}

\section{Introduction}

The interest on gold is not only the reason of the use of gold in jewelry and its shining color, but also it has been found that gold can be used in catalytic converters, metallurgy, energy, electronics, health and environment, and many more applications $[1,2]$. Nowadays, as human knowledge increases, more and more usage of gold has been investigated and it becomes more valuable. Waste water from mining, electroplating industries, electronics, and jewelry making manufacturing are the examples of natural samples which contain trace amount of gold $[3,4]$.

Several methods have been proposed for recovery of gold from waste water such as solvent extraction $[5,6]$, membrane disk [7], ion exchange [8,9], coprecipitation [10, 11], cloud point extraction [12, 13], electrodeposition [14], leaching [15], chlorination [16], cyanidation [17], and solid phase extraction (SPE). Among all these methods, solid phase extraction has some advantages. It has low cost and a high preconcentration factor, and also it is simple, rapid, and efficient [18].

The choice of adsorbent is an important stage in SPE due to control of the analytical parameters such as selectivity, affinity, and capacity [19]. So, different cartridges have been proposed including activated carbon [20], Dowex M 4195 [21], chitin [22], micro beads [23], thiol cotton fiber [24], chelating fiber [25], ion-imprinted polymers [26], modified resin $[27,28]$, polyurethane foam [29], activated alumina [30], and modified silica [31-34]. Among many types of adsorbents used in SPE, functionalized alumina has received great attention for their good mechanical and thermal stability and also less susceptibility to swelling or shrinking [35].

In this paper, for the first time, nanoparticles of alumina are functionalized with 9-acridinylamine group and used for extraction of trace amount of gold ions from some real samples of waste water. The optimum conditions including flow rates of the sample and eluent solution, $\mathrm{pH}$ of the solution, type, and least amount of eluent for elution were 
studied. Also, amount of break through volume, maximum adsorption capacity, and influence of various cationic interferences were investigated. This method can be applied as a reliable method for gold enrichment and determination in complex environmental samples.

\section{Experimental}

2.1. Reagents and Solutions. Analytical reagent grade chemicals-from Merck Company (Darmstadt, Germany) or Fluka Company (Buchs SG, Switzerland)-were employed for the preparation of all solutions. Gold standard solution of $1000 \mu \mathrm{g} \mathrm{mL}^{-1}$ was purchased from Merck (Darmstadt, Germany). Deionized water was used during the experiments. The required $\mathrm{pH}$ adjustments were made by use of the buffer solutions. For the pHs 1 and $2, \mathrm{KCl} / \mathrm{HCl}$ buffer solutions were used. $\mathrm{CH}_{3} \mathrm{COOH} / \mathrm{CH}_{3} \mathrm{COONH}_{4}$ buffers were used to adjust $\mathrm{pH}$ in the range of $4-6$, while $\mathrm{NH}_{3} / \mathrm{NH}_{4} \mathrm{Cl}$ buffers were used for $\mathrm{pHs} 8-10$.

9-Acridinylamine, 3-(chloropropyl)-trimethoxysilane, $\mathrm{CH}_{3} \mathrm{COOH}, \mathrm{Na}_{3} \mathrm{C}_{3} \mathrm{H}_{5} \mathrm{O}\left(\mathrm{CO}_{2}\right)_{3}, \mathrm{Na}_{2} \mathrm{HPO}_{4}, \mathrm{NaH}_{2} \mathrm{PO}_{4}, \mathrm{HCl}$, and $\mathrm{HNO}_{3}$ were purchased from the Merck, and thiourea and thioacetamide were purchased from Fluka.

\subsection{Preparation of 9-Acridinylamine Functionalized Gamma} Alumina Nanoparticles. Gamma alumina nanoparticles were prepared by the sol-gel method. Boehmite sol was prepared by the controlled hydrolysis of aluminum-tri-sec-butoxide. Details of the sol-gel synthesis are reported elsewhere [36]. The sol was dried at $50^{\circ} \mathrm{C}$ to obtain gel pieces and heat treated at $600^{\circ} \mathrm{C}$ to make gamma alumina. BET analysis shows $256 \mathrm{~m}^{2} \mathrm{gr}^{-1}$ surface area for these nanoparticles. The average size of the individual $\gamma$-alumina nanoparticles was calculated as $93 \mathrm{~nm}$ using histogram program.

In order to synthesize 9-acridinylamine functionalized $\gamma$-alumina (py- $\gamma$-alumina), $1 \mathrm{~g} \gamma$-alumina was activated in $\mathrm{NaOH} 2 \mathrm{M}$ for $4 \mathrm{~h}$ then suspended in $50 \mathrm{~mL}$ toluene, and the mixture was stirred for 1 hour. After this step, $2.0 \mathrm{~g}$ of 3-chloropropyl trimethoxy silane was added and refluxed for 12 hours under nitrogen atmosphere. The white solid was removed from the solvent by filtration. The solid was suspended in $50 \mathrm{~mL}$ of triethylamine and toluene, and then 1 gr of 9-acridinylamine was added and refluxed for 6 hours. The white-brownish solid was removed from the solvent by filtration. After this step, it was washed by toluene and chloroform then dried at room temperature. Functionalization by pyridine was confirmed by IR spectroscopy and elemental analysis. IR spectroscopy is given as follows: IR $\left(\mathrm{KBr}, \mathrm{cm}^{-1}\right)-3445(\mathrm{NH}), 3023(\mathrm{CH}$, aromatic) $2913(\mathrm{CH}$, aliphatic), 1545 ( $\mathrm{C}=\mathrm{C}), 600-800$ (alumina). Elemental analysis of py- $\gamma$-alumina sample gave 9 -acridinylamine concentration of $0.49 \mathrm{mmol} \mathrm{g}^{-1}$. The SEM photograph of $\mathrm{py}-\gamma$-alumina nanoparticles is shown in Figure 1. A schematic diagram of synthesis route is shown in Figure 2.

2.3. Instrument. A Shimadzu AA-680 atomic absorption spectrometer (AAS) equipped with single element hollow cathode lamp (6.0 mA for gold) and $10 \mathrm{~cm}$ of burner head and

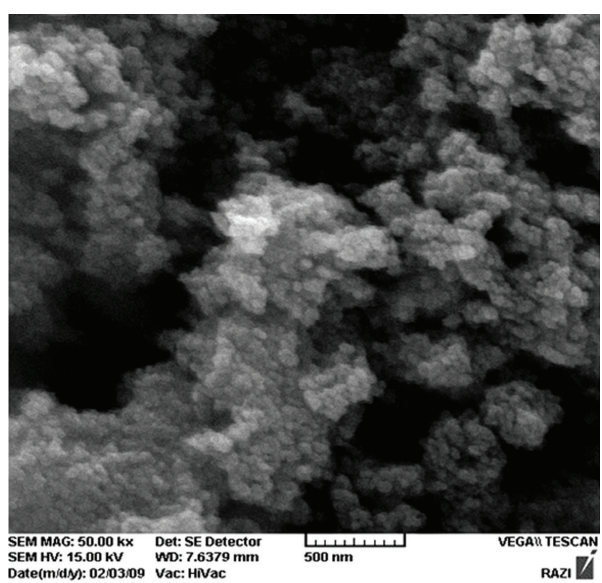

FIgURE 1: SEM photograph of 9-acridinylamine modified nano alumina.

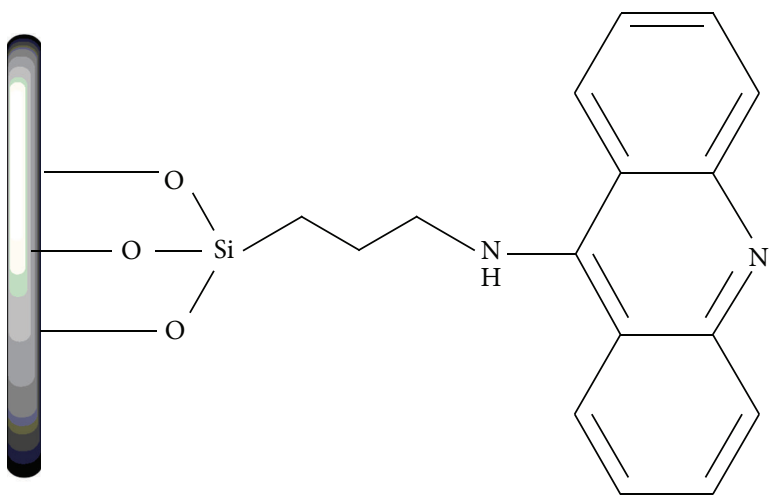

FIGURE 2: A schematic model for 9-acridinylamine modified nano alumina.

air acetylene burner was used for the determination of gold. The wave length at $242.8 \mathrm{~nm}$ (resonance line), the spectral band width at $0.5 \mathrm{~nm}$, and the ratio of air-acetylene at 4.7 were set.

A digital WTW Metrohm 827 ion analyzer (Switzerland) equipped with a combined glass-calomel electrode at $25 \pm$ $1^{\circ} \mathrm{C}$ was used for the $\mathrm{pH}$ measurements.

A vacuum pump from Leybold (Germany) was used during the experiments, and an adjustable vacuum gauge and controller from Analytichem International (Harber City, CA) was used for adjusting flow rate during experiments.

\subsection{Procedure}

2.4.1. Column Procedure. A glass column with $120 \mathrm{~mm}$ in length and $2 \mathrm{~cm}$ in diameter was used for the experiments. It was filled with $200 \mathrm{mg}$ of the alumina. Before using the column, it was washed with $5 \mathrm{~mL}$ dilute hydrochloric acid $1 \mathrm{M}, 5 \mathrm{~mL}$ absolute ethanol, $5 \mathrm{~mL}$ toluene, and $20 \mathrm{~mL}$ distilled water to remove all organic and inorganic impurities.

2.4.2. Preconcentration Procedure. A solution containing $1 \mu \mathrm{g} \mathrm{mL}^{-1}$ of gold was made. Solution's $\mathrm{pH}$ was adjusted to 
to 3 using $\mathrm{Na}_{3} \mathrm{C}_{3} \mathrm{H}_{5} \mathrm{O}\left(\mathrm{CO}_{2}\right)_{3} / \mathrm{HCl}$ buffer solutions. Firstly, buffer solution was passed through the column to precondition it, then $100 \mathrm{~mL}$ of gold solution was passed at flow rate of $6 \mathrm{~mL} \mathrm{~min}^{-1}$. The elution process was performed by passing $8 \mathrm{~mL}$ of thiourea $0.1 \mathrm{~mol} \mathrm{~L}^{-1}$ in $\mathrm{H}_{2} \mathrm{SO}_{4}$ solution $2 \mathrm{~mol} \mathrm{~L}^{-1}$. The eluted solutions were analyzed by FAAS for five times. The results were averaged and reported.

2.4.3. Sample Preparation. Real samples were obtained from tap water in Tehran, Caspian Sea, and jewelry waste water. The solutions were stored in cleaned polyethylene bottles and were filtered before usage. In order to validate the present method, a standard material sample (NCS DC 73323) with a certified gold content was obtained from China National Analysis Center for Iron and Steel. Standard material sample was digested with $6 \mathrm{~mL} \mathrm{HCl} \mathrm{(37 \% )} \mathrm{and} 2 \mathrm{~mL}$ of $\mathrm{HNO}_{3}(65 \%)$ in a microwave digestion system. The microwave program was as follows: $2 \mathrm{~min}$ at $250 \mathrm{~W}, 2 \mathrm{~min}$ without radiation, $6 \mathrm{~min}$ at $250 \mathrm{~W}, 5 \mathrm{~min}$ at $400 \mathrm{~W}, 8 \mathrm{~min}$ at $550 \mathrm{~W}$, and then venting for $8 \mathrm{~min}$. After digestion, it was diluted to $50.0 \mathrm{~mL}$ with deionized water. The $\mathrm{pH}$ of solutions was adjusted by adding $\mathrm{Na}_{3} \mathrm{C}_{3} \mathrm{H}_{5} \mathrm{O}\left(\mathrm{CO}_{2}\right)_{3} / \mathrm{HCl}$ buffer solutions to 3 . The proposed procedure was performed on the samples, and results were reported.

\section{Result and Discussion}

The effect of different parameters on gold extraction was studied. It was tried to find best conditions for extraction. The influence of $\mathrm{pH}$, effect of type, concentration, and volume of eluent, and sample and eluent flow rates were studied, and the optimum values were obtained.

3.1. Influence of $p H$. Considering the important role of $\mathrm{pH}$ on solid phase extraction, the optimum condition for the $\mathrm{pH}$ was obtained by passing $100 \mathrm{~mL}$ of different sample solutions containing $1 \mathrm{mg} \mathrm{L}^{-1}$ gold ion with the $\mathrm{pH}$ range 2-9. Then, the column was washed with $8 \mathrm{~mL}$ of thiourea $0.1 \mathrm{~mol} \mathrm{~L}^{-1}$ in $2 \mathrm{~mol} \mathrm{~L}^{-1} \mathrm{H}_{2} \mathrm{SO}_{4}$, and the eluent was analyzed with FAAS. The optimum condition for extraction was obtained at $\mathrm{pH} 3$ (Figure 3).

3.2. Effect of Type, Concentration, and Volume of Eluent. $\mathrm{HCl}, \mathrm{HNO}_{3}, \mathrm{H}_{2} \mathrm{SO}_{4}$, thiourea, and thioacetamide were mixed in different concentrations to make eluents. These eluents were testified to get the highest recovery in elution. It was observed that $0.1 \mathrm{~mol} \mathrm{~L}^{-1}$ thiourea in $2 \mathrm{~mol} \mathrm{~L}^{-1} \mathrm{H}_{2} \mathrm{SO}_{4}$ solution provided effectiveness of the elution of $\mathrm{Au}$ (III) from sorbent. The optimum volume for elution was $8 \mathrm{~mL}$ of the eluent (Figure 4).

3.3. Sample and Eluent Flow Rates. In order to get the optimum conditions for sample and eluent flow rates, the $\mathrm{pH}$ of $100 \mathrm{~mL}$ of $1 \mu \mathrm{g} \mathrm{mL}^{-1}$ gold solution was adjusted to 3 , and the solution was passed through the column in the flow rate range of $1-15 \mathrm{~mL} \mathrm{~min}^{-1}$. The column was washed with $8 \mathrm{~mL}$ of the optimum eluent. Adsorption of gold ions in the flow
TABLE 1: The tolerance limit of the diverse ions on the determination of gold.

\begin{tabular}{lcc}
\hline Interfering ions & Concentration $\mu \mathrm{g} \mathrm{mL}^{-1}$ & $R \% \pm s$ \\
\hline $\mathrm{Na}^{+}$ & 2000 & $99 \pm 1$ \\
$\mathrm{~K}^{+}$ & 3000 & $98 \pm 2$ \\
$\mathrm{Cs}^{+}$ & 2000 & $99 \pm 2$ \\
$\mathrm{Ca}^{2+}$ & 500 & $98 \pm 2$ \\
$\mathrm{Mg}^{2+}$ & 500 & $99 \pm 1$ \\
$\mathrm{Cd}^{2+}$ & 200 & $98 \pm 1$ \\
$\mathrm{~Pb}^{2+}$ & 100 & $100 \pm 1$ \\
$\mathrm{Cu}^{+2}$ & 50 & $97 \pm 2$ \\
$\mathrm{Cr}^{3+}$ & 200 & $99 \pm 1$ \\
$\mathrm{Fe}^{2+}$ & 300 & $99 \pm 1$ \\
\hline
\end{tabular}

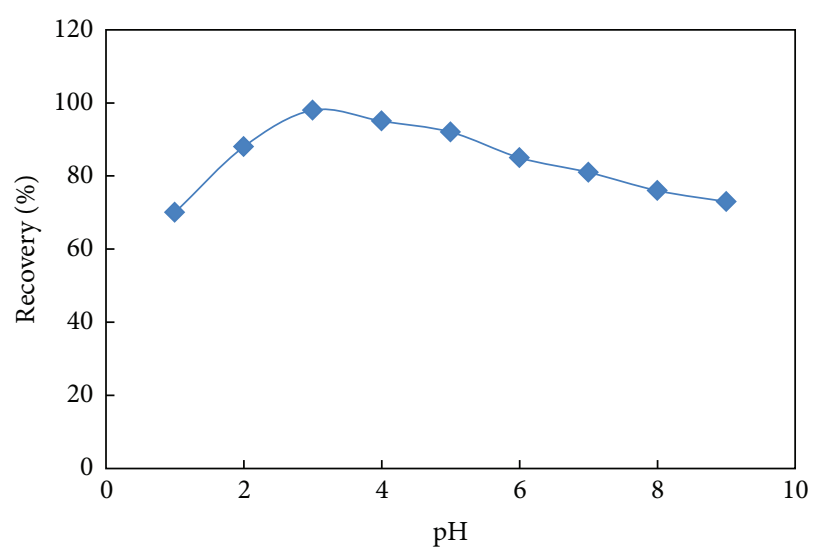

FIGURE 3: Effect of $\mathrm{pH}$ of sample solution on percent recovery of $\mathrm{Au}(\mathrm{III})$ by 9-acridinylamine alumina.

rates higher than $9 \mathrm{~mL} \mathrm{~min}^{-1}$ was not complete (Figure 5). So, the optimum flow rate should be around $6 \mathrm{~mL} / \mathrm{min}$ so that any small variation in the flow rate will not affect the adsorption. The flow rate for elution was also studied and observed so that flow rates $3 \mathrm{~mL} \mathrm{~min}^{-1}$ and less show good recoveries.

3.4. Influence of Interference Ions. The efficiency of the method in the presence of different cations was studied. The cations of $\mathrm{Na}^{+}, \mathrm{K}^{+}, \mathrm{Cs}^{+}, \mathrm{Mg}^{2+}, \mathrm{Ca}^{2+}, \mathrm{Cd}^{2+}, \mathrm{Fe}^{2+}, \mathrm{Cu}^{2+}, \mathrm{Pb}^{2+}$, and $\mathrm{Cr}^{3+}$ as their chloride salts with various concentrations were added to $100 \mathrm{~mL}$ of single solution containing $1 \mathrm{mg}$ of gold, and the extraction procedure was followed. The results showed that presence of these cations has no effect on recovery of gold ions (Table 1).

3.5. Maximum Adsorption Capacity. Maximum adsorption capacity of the sorbent was studied by passing $500 \mathrm{~mL}$ portions of aqueous single solutions containing $100 \mathrm{mg}$ gold through the column, followed by determination of the effluent and retained metal ions using FAAS. The maximum capacity was $38 \pm 2 \mathrm{mg} \mathrm{g}^{-1}\left(0.2 \pm 0.01 \mathrm{mmol} \mathrm{g}^{-1}\right)$. 
TABLE 2: Data of real sample analysis for Au on 9-acridinylamine alumina.

\begin{tabular}{|c|c|c|c|c|}
\hline & Real sample (ng mL ${ }^{-1}$ ) & Added $\left(\mathrm{ng} \mathrm{mL} L^{-1}\right)$ & Found (ng mL $L^{-1}$ ) & Recovery (\%) \\
\hline Distilled water & ND & 5.00 & $4.95 \pm 0.10$ & 99 \\
\hline Tap water & ND & 5.00 & $4.89 \pm 0.10$ & 98 \\
\hline Waste water & 12.31 & 40.00 & $51.81 \pm 0.10$ & 99 \\
\hline Sea water & 8.00 & 40.00 & $45.64 \pm 0.10$ & 96 \\
\hline Standard material & 260.00 & 0.00 & $265.33 \pm 2.41$ & 102 \\
\hline
\end{tabular}

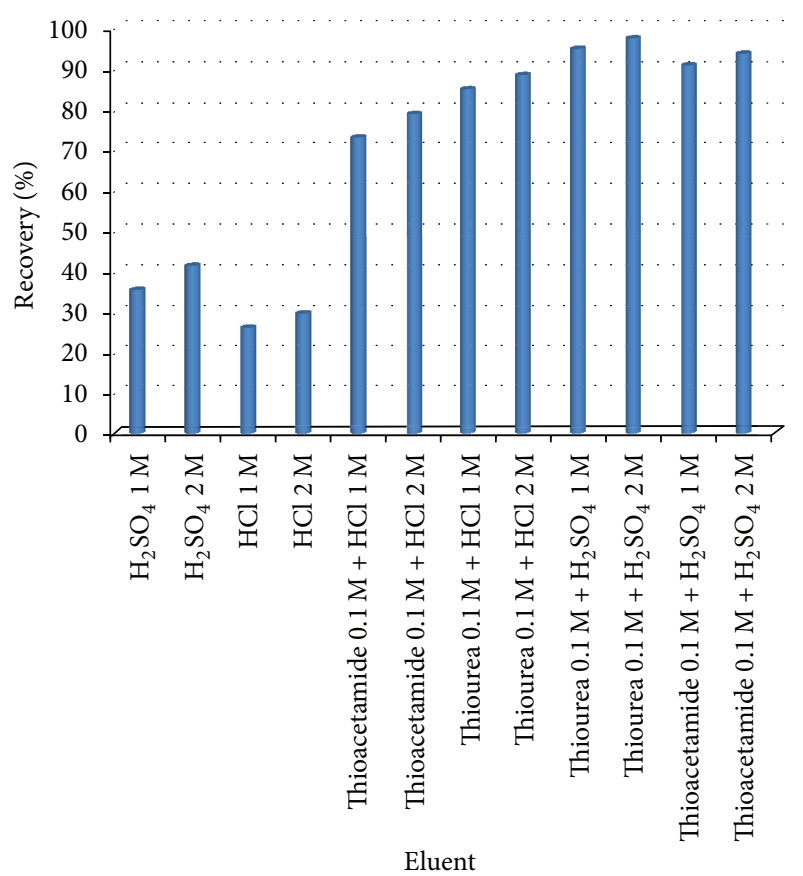

FIGURE 4: Effect of type and concentration of eluent for desorption of $\mathrm{Au}(\mathrm{III})$ by 9 -acridinylamine alumina.

3.6. Analytical Performance. The enrichment factor was determined by the recommended column procedure using increasing volumes of $1 \mu \mathrm{g} \mathrm{mL}^{-1}$ Au solution. The maximum sample volumes were found to be $600 \mathrm{~mL}$ for nano alumina with recovery greater than $98.5 \%$. The loaded gold ions were easily desorbed from the solid phases with their respective eluent volume. Subsequently, they were subject to boiling until the volume reaches $3 \mathrm{~mL}$. As a result, enrichment factors as high as 200 on nano alumina were obtained.

To determine the detection limit of the present method, $500 \mathrm{~mL}$ blank solutions $(n=10)$ were passed through the column under the optimum experimental conditions. The values of LOD for gold on modified nano alumina are $13.00 \mathrm{ppb}$. The results were obtained from CLOD $=K_{b} S_{b} / \mathrm{m}$, where $k_{b}=3$.

The precision of the method under the optimum conditions was determined by performing ten replicates. The recoveries were found to be $98.5 \% \pm 1.2$ on modified alumina. In order to investigate the accuracy and applicability of this method, real samples and standard material were analyzed. With these analyses, the effect of different matrices on the method was studied. For sample preparation, certain

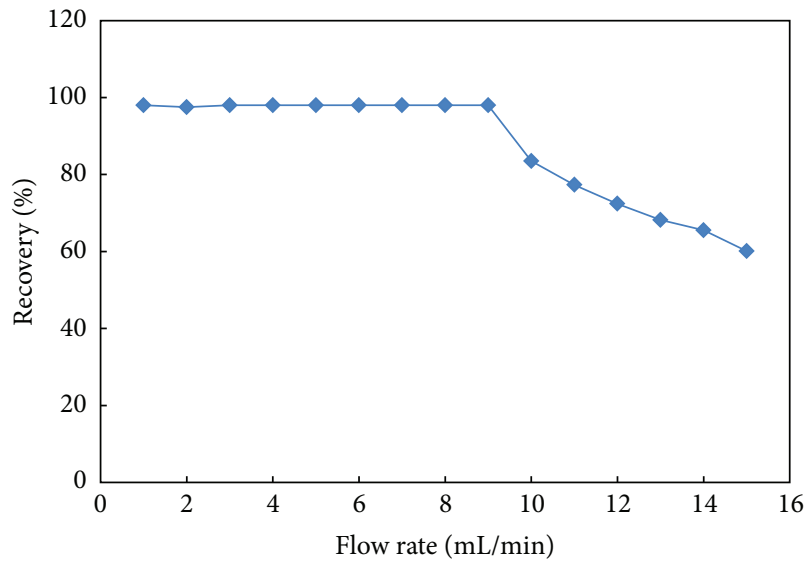

Figure 5: Effect of flow rates of sample solutions on the percent recovery of $\mathrm{Au}(\mathrm{III})$ by 9 -acridinylamine alumina.

amounts of gold were spiked into the samples (Table 2). As shown, in all cases, the recovery is almost quantitative.

\section{Conclusions}

Solid phase extraction procedure based on modified gamma Alumina is very simple, fast, reproducible, and selective. Compared with other solid phases, 9-acridinylamine functional gamma alumina has some benefits, like high capacity factor, low detection limit, and high enrichment factor. Due to relative high preconcentration factor, trace metal ions at ppb level in high volume economical sample can be determined and separated by them.

\section{References}

[1] I. H. El-Sayed, X. Huang, and M. A. El-Sayed, "Surface plasmon resonance scattering and absorption of anti-EGFR antibody conjugated gold nanoparticles in cancer diagnostics: applications in oral cancer," Nano Letters, vol. 5, no. 5, pp. 829-834, 2005.

[2] Z. X. Su, Q. S. Pu, X. Y. Luo, X. J. Chang, G. Y. Zhan, and F. Z. Ren, "Application of a macroporous resin containing imidazoline groups to preconcentration and separation of gold, platinum and palladium prior to ICP-AES determination," Talanta, vol. 42, no. 8, pp. 1127-1133, 1995.

[3] J. M. Macy, K. Nunan, K. D. Hagen et al., "Chrysiogenes arsenatis gen. nov., sp. nov., a new arsenate-respiring bacterium isolated from gold mine wastewater," International Journal of Systematic Bacteriology, vol. 46, no. 4, pp. 1153-1157, 1996. 
[4] L. Monser and N. Adhoum, "Modified activated carbon for the removal of copper, zinc, chromium and cyanide from wastewater," Separation and Purification Technology, vol. 26, no. 2-3, pp. 137-146, 2002.

[5] Imdadullah, T. Fujiwara, and T. Kumamaru, "Solvent extraction and chemiluminescence determination of gold in silver alloy with luminol in reverse micelles," Analytical Chemistry, vol. 65, no. 4, pp. 421-424, 1993.

[6] S. Akita, L. Yang, and H. Takeuchi, "Solvent extraction of gold(III) from hydrochloric acid media by nonionic surfactants," Hydrometallurgy, vol. 43, no. 1-3, pp. 37-46, 1996.

[7] M. Bagheri, M. H. Mashhadizadeh, and S. Razee, "Solid phase extraction of gold by sorption on octadecyl silica membrane disks modified with pentathia-15-crown-5 and determination by AAS," Talanta, vol. 60, no. 4, pp. 839-844, 2003.

[8] C. P. Gomes, M. F. Almeida, and J. M. Loureiro, "Gold recovery with ion exchange used resins," Separation and Purification Technology, vol. 24, no. 1-2, pp. 35-57, 2001.

[9] M. Grote and A. Kettrup, "Ion-exchange resins containing Sbonded dithizone and dehydrodithizone as functional groups: part 1. Preparation of the resins and investigation of the sorption of noble metals and base metals," Analytica Chimica Acta, vol. 172, pp. 223-239, 1985.

[10] S. Arpadjan, L. Jordanova, and I. Karadjova, "Reductive coprecipitation and extraction as separation methods for the determination of gold in copper concentrates by AAS and ICP-AES," Fresenius' Journal of Analytical Chemistry, vol. 347, no. 12, pp. 480-482, 1993.

[11] M. Soylak and M. Tuzen, "Coprecipitation of gold(III), palladium(II) and lead(II) for their flame atomic absorption spectrometric determinations," Journal of Hazardous Materials, vol. 152, no. 2, pp. 656-661, 2008.

[12] S. Akita, A. M. Sastre, H. Takeuchi, and M. Rovira, "Cloud-point extraction of gold(1ll) with nonionic surfactant-fundamental studies and spplication to gold recovery from printed substrate," Separation Science and Technology, vol. 33, no. 14, pp. 2159-2177, 1998.

[13] M. A. Mesquita da Silva, V. L. A. Frescura, and A. J. Curtius, "Determination of noble metals in biological samples by electrothermal vaporization inductively coupled plasma mass spectrometry, following cloud point extraction," Spectrochimica Acta B, vol. 56, no. 10, pp. 1941-1949, 2001.

[14] J. Komárek and P. Houserová, "Determination of gold by electrothermal atomic absorption spectrometry after electrodeposition on a graphite tube," Spectrochimica Acta B, vol. 58, no. 8, pp. 1525-1530, 2003.

[15] D. Zipperian, S. Raghavan, and J. P. Wilson, "Gold and silver extraction by ammoniacal thiosulfate leaching from a rhyolite ore," Hydrometallurgy, vol. 19, no. 3, pp. 361-375, 1988.

[16] B. Dönmez, Z. Ekinci, C. Çelik, and S. Çolak, "Optimisation of the chlorination of gold in decopperized anode slime in aqueous medium," Hydrometallurgy, vol. 52, no. 1, pp. 81-90, 1999.

[17] P. D. Kondos, G. Deschênes, and R. M. Morrison, "Process optimization studies in gold cyanidation," Hydrometallurgy, vol. 39, no. 1-3, pp. 235-250, 1995.

[18] M. Bagheri, M. H. Mashhadizadeh, and S. Razee, "Solid phase extraction of gold by sorption on octadecyl silica membrane disks modified with pentathia-15-crown-5 and determination by AAS," Talanta, vol. 60, no. 4, pp. 839-844, 2003.

[19] S. Sadeghi and E. Sheikhzadeh, "Solid phase extraction using silica gel modified with murexide for preconcentration of uranium (VI) ions from water samples," Journal of Hazardous Materials, vol. 163, no. 2-3, pp. 861-868, 2008.

[20] G. Chakrapani, P. L. Mahanta, D. S. R. Murty, and B. Gomathy, "Preconcentration of traces of gold, silver and palladium on activated carbon and its determination in geological samples by flame AAS after wet ashing," Talanta, vol. 53, no. 6, pp. 1139-1147, 2001.

[21] M. Tuzen, K. O. Saygi, and M. Soylak, "Novel solid phase extraction procedure for gold(III) on Dowex M 4195 prior to its flame atomic absorption spectrometric determination," Journal of Hazardous Materials, vol. 156, no. 1-3, pp. 591-595, 2008.

[22] K. Terada and H. Kawamura, "preconcentration of gold (III), palladium (II) and ruthenium(III) with dithiocarbamatechitin," Analytical Sciences, vol. 7, pp. 71-74, 1991.

[23] C. Kavakl, N. Özvatan, S. A. Tuncel, and B. Salih, "1,4,8,11Tetraazacyclotetradecane bound to poly( $p$-chloromethylstyrene-ethylene glycol dimethacrylate) microbeads for selective gold uptake," Analytica Chimica Acta, vol. 464, no. 2, pp. 313-322, 2002.

[24] M. Yu, D. Sun, R. Huang et al., "Determination of ultra-trace gold in natural water by graphite furnace atomic absorption spectrophotometry after in situ enrichment with thiol cotton fiber," Analytica Chimica Acta, vol. 479, no. 2, pp. 225-231, 2003.

[25] L. Weiping, L. Yun, and Z. Hanmin, "Preparation of the amidoxime group containing chelating fiber and adsorption property of gold. I. Preparation of chelating fiber by amidoximation of polyacrylonitrile fiber," Reactive Polymers, vol. 17, no. 3, pp. 255-261, 1992.

[26] S. Daniel, P. P. Rao, and T. P. Rao, "Investigation of different polymerization methods on the analytical performance of palladium(II) ion imprinted polymer materials," Analytica Chimica Acta, vol. 536, no. 1-2, pp. 197-206, 2005.

[27] A. Warshawsky, N. Kahana, V. Kampel et al., "Ion exchange resins for gold cyanide extraction containing a piperazine functionality, Synthesis and physico-chemical properties," Macromolecular Materials and Engineering, vol. 283, no. 1, p. 103, 2000.

[28] J. L. Cortina, A. Warshawsky, N. Kahana, V. Kampel, C. H. Sampaio, and R. M. Kautzmann, "Kinetics of goldcyanide extraction using ion-exchange resins containing piperazine functionality," Reactive and Functional Polymers, vol. 54, no. 1-3, pp. 25-35, 2003.

[29] T. Braun and A. B. Farag, "The recovery of gold from thiourea solutions with open-cell polyurethane foams," Analytica Chimica Acta, vol. 66, no. 3, pp. 419-426, 1973.

[30] X. Pu, Z. Jiang, B. Hu, and H. Wang, " $\gamma$-MPTMS modified nanometer-sized alumina micro-column separation and preconcentration of trace amounts of $\mathrm{Hg}, \mathrm{Cu}, \mathrm{Au}$ and $\mathrm{Pd}$ in biological, environmental and geological samples and their determination by inductively coupled plasma mass spectrometry," Journal of Analytical Atomic Spectrometry, vol. 19, pp. 984-989, 2004.

[31] S. S. Bozkurt and M. Merdivan, "Solid phase extraction of gold(III) on silica gel modified with benzoylthiourea prior to its determination by flame atomic absorption spectrometry," Environmental Monitoring and Assessment, vol. 158, no. 1-4, pp. 15-21, 2009.

[32] A. Goswami and A. K. Singh, "Silica gel functionalized with resacetophenone: synthesis of a new chelating matrix and its application as metal ion collector for their flame atomic 
absorption spectrometric determination," Analytica Chimica Acta, vol. 454, no. 2, pp. 229-240, 2002.

[33] J. Hájková, V. Kanický, and V. Otruba, "Preconcentration and separation of gold on modified silica gel," Collection of Czechoslovak Chemical Communications, vol. 65, pp. 1848-1864, 2000.

[34] M. A. A. Akl, I. M. M. Kenawy, and R. R. Lasheen, "Organically modified silica gel and flame atomic absorption spectrometry: employment for separation and preconcentration of nine trace heavy metals for their determination in natural aqueous systems," Microchemical Journal, vol. 78, no. 2, pp. 143-156, 2004.

[35] E. M. Soliman, M. B. Saleh, and S. A. Ahmed, "Alumina modified by dimethyl sulfoxide as a new selective solid phase extractor for separation and preconcentration of inorganic mercury(II)," Talanta, vol. 69, no. 1, pp. 55-60, 2006.

[36] Y. K. Park, E. H. Tadd, M. Zubris, and R. Tannenbaum, "Sizecontrolled synthesis of alumina nanoparticles from aluminum alkoxides," Materials Research Bulletin, vol. 40, no. 9, pp. 1506-1512, 2005. 

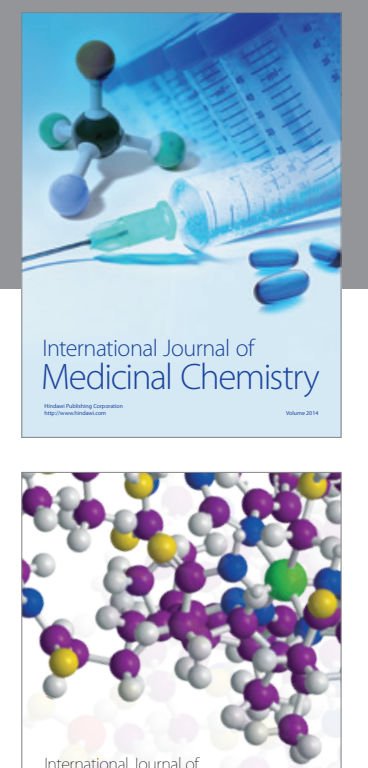

\section{Carbohydrate} Chemistry

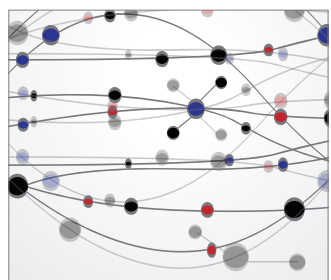

The Scientific World Journal
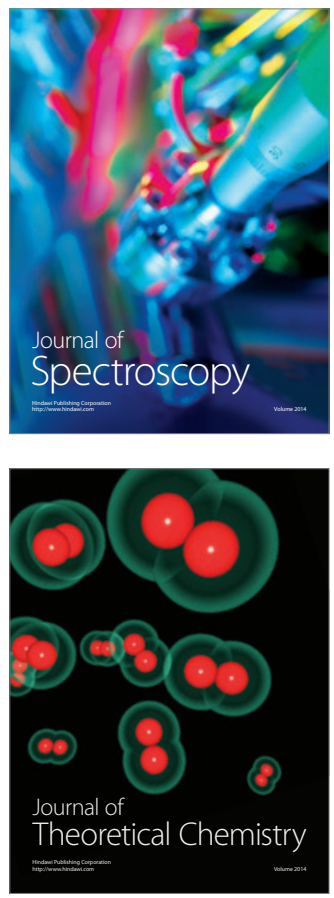
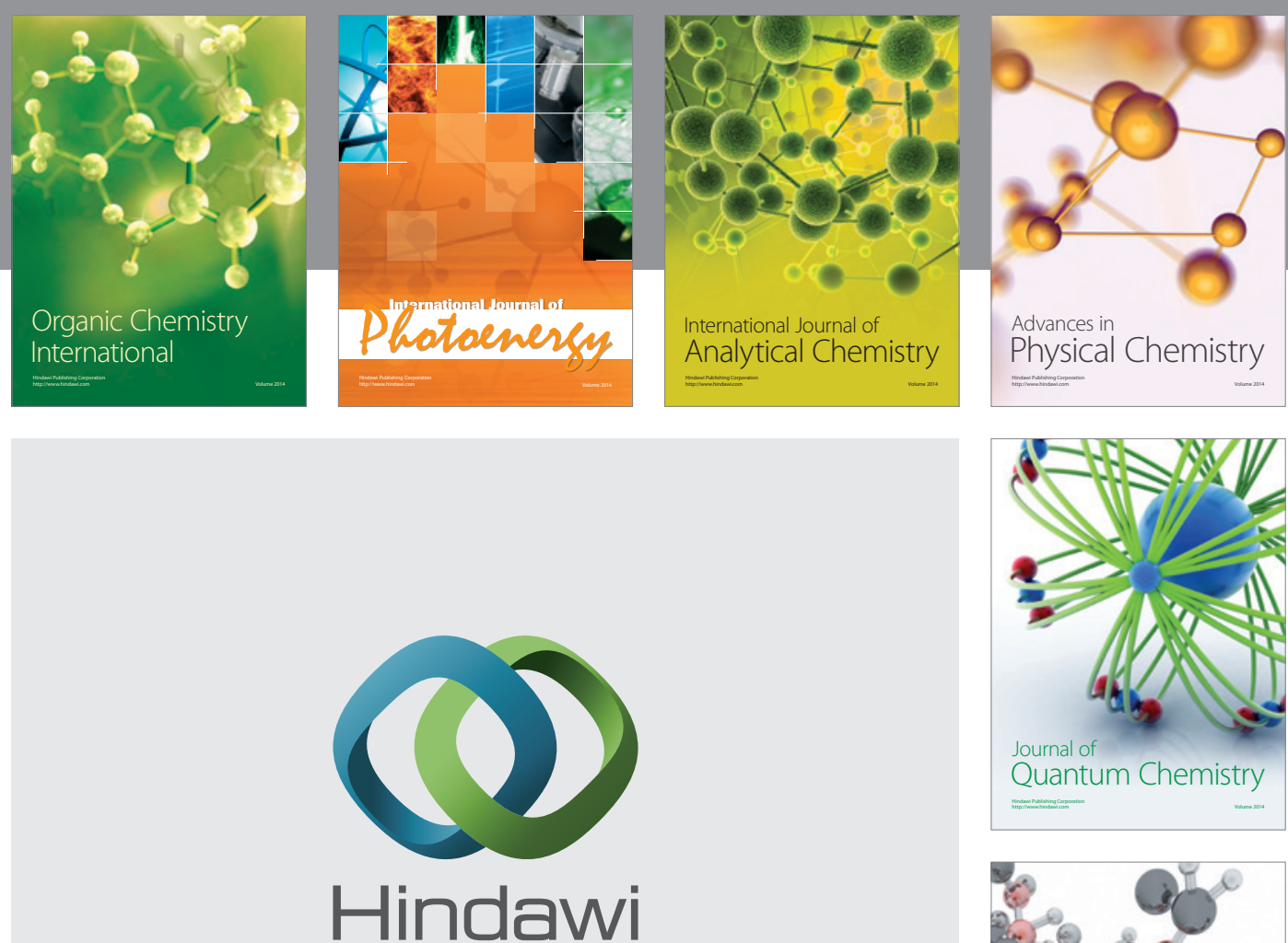

Submit your manuscripts at

http://www.hindawi.com

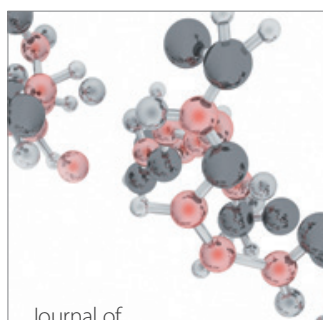

Analytical Methods

in Chemistry

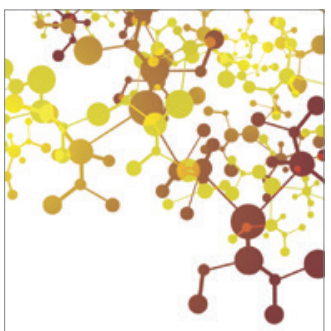

Journal of

Applied Chemistry

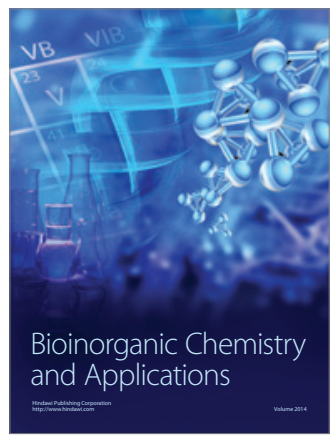

Inorganic Chemistry
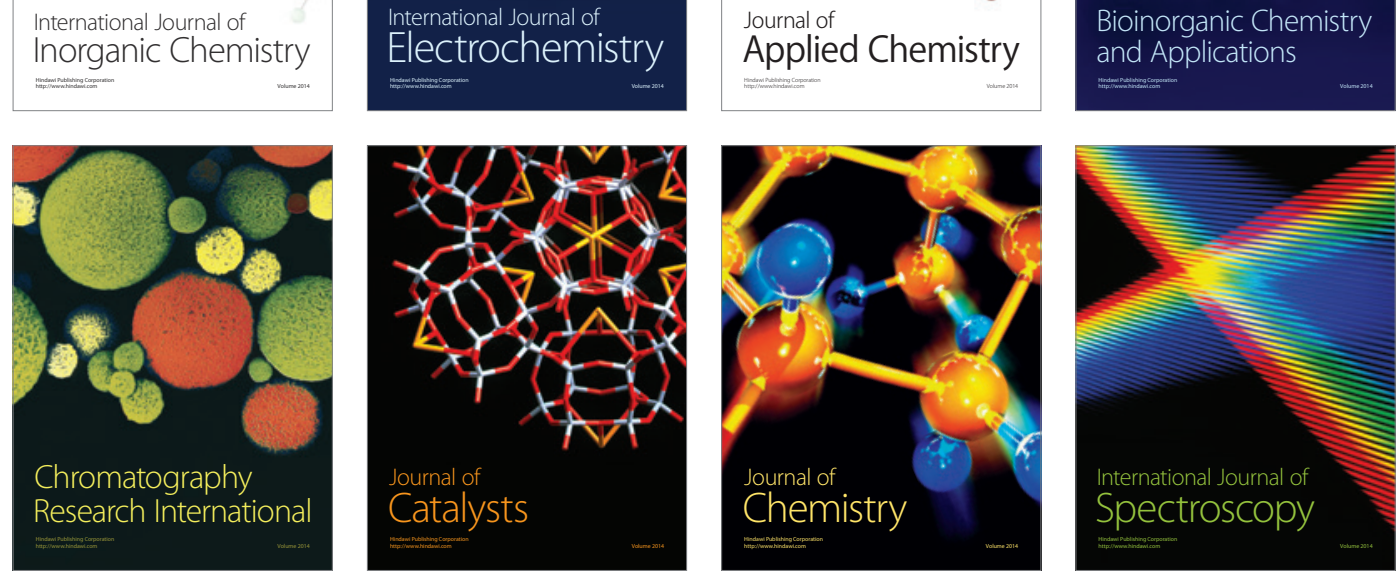